\title{
An Empirical Study on the Effect of Instruction on Metacognitive Strategies on EFL Reading Comprehension: The Case of Foundation-Level Students in Oman
}

\author{
Omaima Al-Kiyumi ${ }^{1}$, Fawzia Al Seyabi ${ }^{2} \&$ Abdul Hamid Hassan ${ }^{2}$ \\ ${ }^{1}$ Waljat College of Applied Sciences, Oman \\ ${ }^{2}$ Sultan Qaboos University, Oman \\ Correspondence: Fawzia Al Seyabi, Sultan Qaboos University, Oman. E-mail: fawzia@squ.edu.om
}

Received: September 30, 2020

Accepted: April 26, $2021 \quad$ Online Published: July 22, 2021

doi: $10.5539 /$ ies.v14n8p30

URL: https://doi.org/10.5539/ies.v14n8p30

\begin{abstract}
The current quasi-experimental study investigated the effect of metacognitive reading strategies on the reading comprehension and attitudes of Omani EFL foundation-level students. The sample of the study included two intact classes $(\mathrm{N}=45)$ and was selected based on the students' results in the midterm reading comprehension exam and their responses to the metacognitive strategies survey (MARSI). One class functioned as the experimental group, which received instruction relating to the metacognitive reading strategies. The other class was the control group which received conventional reading instruction. Two instruments were used to collect data: a pre-post reading comprehension test to measure the students' performance in reading and an attitude questionnaire to investigate their attitudes towards metacognitive reading strategies use. The results of the study revealed that there was a statistically significant difference between the learners' reading comprehension in the experimental group and the control group in favor of the experimental group as a result of metacognitive reading strategies instruction. Results also showed that students in the experimental group held positive attitudes towards using metacognitive reading strategies use. In the light of these findings, implications and recommendations for practice were put forward.
\end{abstract}

Keywords: attitude, EFL, foundation programs, metacognitive strategies, Oman, reading

\section{Introduction}

Due to its intimate relationship with knowledge transmission and expansion, reading has become an indispensable skill in academic settings (Al Seyabi \& Tuzlukova, 2015). However, given the complexity of reading as a language skill, Grabe and Stoller (2002) maintain that becoming a proficient reader is not an easy task. Poor reading can hinder academic success for many second language learners who may struggle to comprehend content presented in academic subjects. In fact, in various EFL and ESL settings, concerns have been raised about students' unpreparedness to meet college reading requirements, especially where the medium of instruction is dominantly English (Al Seyabi \& Tuzlukova, 2015; Cahyono \& Widiati, 2006; Moss \& Bordelon, 2007; Sivaraman, Al Balushi, \& Rao, 2014). Although part of the problem is attributed to students' poor language levels (Snow, 2002), a major reason that the literature often cites is students' lack of reading strategies such as self-planning, self-monitoring, self-regulating and self-evaluating (Tavakoli, 2014; Al Rabah \& Wu, 2019; Al-Mekhlafi, 2018).

According to Caverly, Nicholson, and Radcliffe (2004), Mokhtari and Reichard (2002), and Pressley and Afflerbach (1995), attaining academic goals relies on learners' ability to become strategic readers who implement a range of learning techniques including metacognitive reading strategies. However, prior research in second language acquisition has shown that most ESL readers tend to have problems with using effective reading strategies either due to a lack of knowledge of these strategies or because of inappropriate use (Yore, Craig, \& Maguire, 1998). Moreover, studies have demonstrated that when readers who are competent in their first language read in a second language, they become 'text-bound' and fail to successfully utilize the reading strategies that they use when approaching a text in their first language (Lau \& Chan, 2003).

Readers deficient in metacognitive awareness tend to spend extra time trying to understand single words rather than making meaning from connected text. Maintaining metacognitive reading strategies as well as appropriately utilizing them, results in learners being more involved, interactive and responsive to allotted materials (Mokhtari 
\& Sheorey, 2002). O'Malley and Chamot (1990) emphasized that "students without metacognitive approaches are essentially learners without direction or opportunity to plan their learning, monitor their progress or review their accomplishments and future directions" (p. 8). Likewise, Zhang and Seepho (2012) maintain that metacognitive strategies are important for successful foreign language readers. In light of these findings, it is imperative for both college stakeholders and EFL learners to address the importance of metacognitive reading strategies to ensure better academic outcomes.

In Oman, low English reading performance is not restricted to primary or secondary education learners; the higher education sector is also dealing with low reading achievers. In 2008, following Ministerial Decision No.72/2008, all Higher Education Institutions (HEIs), both public and private operating in the Sultanate of Oman had to implement the national academic standards for General Foundation Programs (GFP) embraced by Oman Academic Accreditation Authority (OAAA, 2008). These standards were designed to improve academic outcomes at the tertiary level. Learning outcomes in four areas: English, Math, IT and general study skills, shaped the GFP standards framework (Carroll, Razvi, \& Goodliffe, 2009). However, since HEIs started implementing the standards in the 2008-2009 academic year, GPF providers have encountered many challenges, including low English language proficiency, and gaps between post-secondary ability and higher education requirements (Al-Mamari, 2010). Schools have been held responsible for the low English results achieved by students who are lacking essential knowledge and skills required for college (Cahyono \& Widiati, 2006; Moss \& Bordelon, 2007).

In various EFL and ESL contexts, concerns have been raised about students' unpreparedness to meet college and university requirements (Al-Mahrooqi \& Asante, 2010; Al Seyabi \& Tuzlukova, 2015; Cahyono \& Widiati, 2006; Moody, 2009; Moss \& Bordelon, 2007; Sivaraman \& Al Balushi, 2014). In Oman, most secondary school graduates are required to enroll in English foundation programs on entering higher education institutes. In their paper, Understanding Omani Students' (University) English Language Problems, Sivaraman and Al Balushi (2014) found that due to a lack of proficiency in English, Omani college students' performance in modules, their class participation and exam preparation was directly affected. Cobb (1999) found that Omani freshmen struggle the most with reading as compared to the other three English language skills (writing, speaking and listening). The weak reading skills uncovered by Cobb's study was thought to be due to comprehension deficiency caused by the inability to understand words and construct meanings (cited in Al-Mahrooqi, 2012).

Similar to other EFL settings, Waljat College of Applied Sciences, a private college in Oman utilizes guided reading textbooks in which the prime focus of accompanying texts is on vocabulary items, sentence patterns and grammatical structures. Incorporating reading strategies, according to Singhal (2001), ultimately improves text comprehension and enhances language learning. Consequently, EFL learners need to be aware of their reading strategies in order to assist their language learning.

This research is an attempt to find out whether the teaching of meta-cognitive strategies affects EFL freshmen foundation-level students' reading comprehension. Moreover, it aims to explore students' attitudes towards direct instruction on metacognitive strategies. In particular, the research attempts to answer the following research questions: 1) What is the effect of metacognitive reading strategies instruction on the reading comprehension performance of EFL foundation-level students? and 2) What are students' attitudes towards the use of metacognitive reading strategies?

It is hoped that the results of this study may contribute to the existing body of literature in the field of EFL metacognitive reading strategies use in college settings and assist curriculum designers to develop effective college reading programs that conceptualize metacognitive reading comprehension strategies within assigned reading materials and ultimately increase students' chances of college success.

\section{Literature Review}

\subsection{Metacognitive Reading Strategies}

Oxford (1990) defined learning strategies as "specific actions taken by the learner to make learning easier, faster, more enjoyable, more self-directed, more effective, and more transferable to new situations". Besides, Wenden and Rubin (1987) noted that learning strategies are ways in which learners contribute to the development of their language system. They allow learners to respond appropriately to specific learning situations and learn something more effectively.

Oxford (1990) classified learning strategies into direct and indirect. In her view, as illustrated in Figure 1, direct strategies involve memory strategies, compensation strategies and cognitive strategies. On the other hand, indirect strategies encompass affective strategies, social strategies and metacognitive strategies. The current study is mainly concerned with metacognitive reading strategies. These strategies refer to the mental steps or 
operations used by learners which require direct analysis, transformation, or synthesis of learning materials (O'Malley \& Chamot, 1990). They operate directly on new information and control it to promote learning (O'Malley \& Chamot, 1990). They enable students to understand and produce the new language in different ways including repeating, predicting, using context clues, note-taking, summarizing, reasoning deductively, analyzing and practicing.

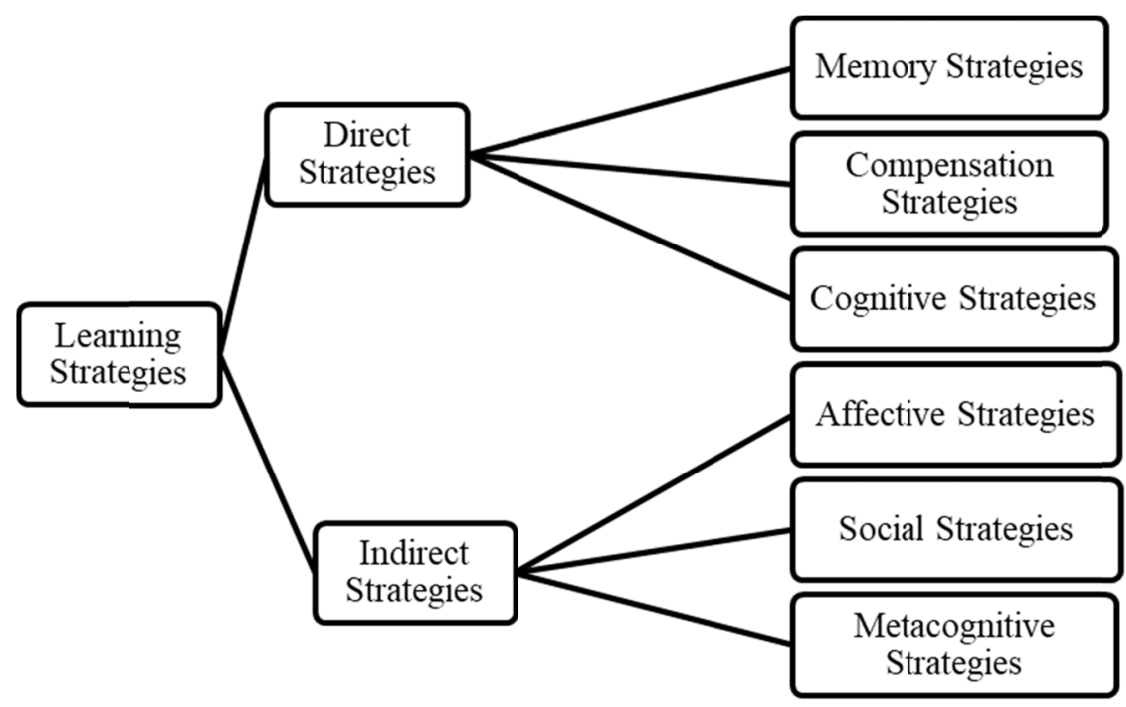

Figure 1. Direct and indirect strategies (Oxford, 1990)

Previous research has indicated that cognitive learning strategies have a positive impact on successful second and foreign language learning (Ozek \& Civelek, 2006; Ratna, 2014). The importance of cognitive strategies increases with the mental growth of learners. That is, younger learners tend to develop less cognitive strategies than older learners as physical growth takes place.

According to Lam (2008), metacognitive strategies are strategies that involve thinking about the learning process rather than being task-specific and thus can be applied to diverse types of learning tasks. For Guterman (2003), metacognition, meta-comprehension, metalinguistics and metacognitive awareness are crucial in activating the learner's schemata. Essentially, these hold many assumptions. First, they assume that the reader is aware of the various factors involved in the learning situation, such as text characteristics, task requirements, and appropriate strategies and the reader's abilities and deficiencies. Second, these concepts assume that the reader is aware of different kinds of previous knowledge (including cultural and social knowledge) which can be used to construct meaning. Moreover, the reader is aware that using previous experience and background will influence their ability to learn from reading and will in turn affect learning performance. The reader is also viewed as being able to use this prior knowledge consciously and deliberately. These cognitive concepts have much in common with the concepts of the zone of proximal development (ZPD) and scaffolding as postulated by Vygotsky. In all these examples the individual is thought of as an active agent in his or her cognitive development (Guterman, 2003). This is especially applicable in the current study as students are prepared to become autonomous learners.

Metacognitive reading strategies are techniques employed by readers to build comprehension. These strategies are considered high order executive skills that allow readers to use their knowledge of cognitive processes to regulate their learning. They include self-monitoring and self-regulating activities which can be applied to the reading process as well as the product. Knowledge of these metacognitive strategies can help readers 1) gain confidence in their ability to comprehend a text, 2) more effectively determine the cognitive demands that each reading task will entail, and 3) raise their awareness of when to employ cognitive reading strategies based on passage difficulty, situational variables, and the readers' cognitive abilities (Baker \& Brown, 1984; Carrell, 1989; Chamot, 2005).

Metacognitive reading strategies can be grouped into three distinct clusters of planning, monitoring, and evaluating strategies (Israel, 2007; Pressley \& Afflerbach, 1995). To use Mokhtari and Reichard's (2002) taxonomy, these metacognitive clusters can be of three different types: global (planning) strategies, problem-solving (monitoring) strategies, and support (evaluating) strategies. 
Planning strategies, also called global strategies, are used before the actual reading stage. They are intended to prepare the reader's cognition to grasp the overview of the text. They are effective in the sense that they stimulate the learner's cognition to pave the way for comprehension. Moreover, they facilitate the learners' active involvement in the passage themes and concepts. Pre-reading or planning strategies prepare students to form a purpose for reading; preview titles and illustrations; make predictions; and notice structure, headings, and subheadings. Utilizing such strategies enables readers to develop a broad understanding of the main ideas of a text. They can also check whether the presented text has a specific structure such as description and episode, generalization and principle, concept and definition, cause and effect, comparison and contrast, question and answer or problem and solution (Israel, 2007).

Monitoring strategies or problem-solving strategies form the second cluster of metacognitive reading strategies. This cluster encompasses strategies applied during the reading stage to control comprehension. These strategies are crucial in shaping what happens in the reader's mind. Through their use students can thoroughly structure their reading process and promote active reading skills which consequently help students make sense of a text. Monitoring strategies include monitoring understanding, stopping to summarize and check comprehension, making connections, inferring main ideas for each paragraph and asking questions (Israel, 2007; 1991; Pressley, 2002).

The process of readers actively engaging with a text does not end once the reading is completed. Post-reading strategies, which are also called evaluating or support strategies, are equally important to foster active learning. Such strategies guide learners as they cognitively process the information they are exposed to within the text. They guide students as they process the information they have read and help them to systematically implement their deep thinking skills to clarify ambiguous points, connect related ideas, form relevant opinions, come up with evaluative questions and develop critical ideas from reading (Pressley, 2002). Utilizing post-reading strategies offers opportunities to not only improve learners' metacognitive abilities but also establish better comprehension and ultimately better language learning (Israel, 2007).

Metacognition is not a linear process that helps the reader progress from the first cognitive stage of simply scanning through to the final stage of analysis and evaluation. It might combine more than one metacognitive process at any given time to aid a reader during a learning task (Marimuthu, Muthusamy, \& Veeravagu, 2016).

In summary, metacognitive strategies are high order executive skills that make use of knowledge of cognitive processes and involve thinking about the learning process, planning for learning (pre-reading phase), monitoring the learning task (reading phase), and evaluating how well one has learned (post-reading phase) (Chamot \& Kupper, 1989; Wenden, 1998).

\subsection{Metacognitive Strategies Instruction}

In the 1990s, there was a prominent shift within the field of language learning and teaching with more emphasis being put on learners and the learning process rather than on teachers and the teaching process. In parallel to this shift, researchers shifted from simply describing and classifying learning strategies to examining the effect of different interventions in classroom settings (Hismanoglu, 2000).

According to Carrell et al. (1989), reading instruction often involves either direct instruction of decoding skills or informal teaching of comprehension. Anderson, Hiebert, Scott, and Wilkinson (1985) conclude that direct instruction can be used for improving comprehension but needs to be distinguished from questioning, discussion, and guided practice. They describe direct instruction in comprehension as explaining or modelling the steps in a thought process that leads to better comprehension. Their recommendation is for the teacher to model a strategy by thinking aloud about how he or she is developing an understanding of a passage. The instruction should also include information regarding why and when to use the strategy. Instruction of this type is the most certain means of developing strategic processing which is a characteristic of skilled readers (p. 72).

Explicit strategies instruction raises learners' consciousness of both their strategy use and the existence of other strategies (Oxford, 1990). In terms of comprehension instruction, Reutzel, Smith, and Fawson (2005) pointed out that much importance has been attached to the instruction of cognitive strategies, which has evolved from the teaching of single cognitive comprehension strategies in isolation to the teaching of multiple 'sets' or 'families' of cognitive comprehension strategies in coordinated use.

\section{Method}

\subsection{Research Design}

This study has a quasi-experimental design which 'aims to demonstrate causality between an intervention and an outcome' (Harris et al., 2006). Quasi-experimental designs are used to test hypotheses investigating the effects of 
manipulable intervention but lack the random assignment that occurs with true experimental designs (Shadish, \& Luellen, 2005). These types of studies usually evaluate how well a new treatment may work (William, Shadish, Cook, \& Campbell, 2002). Two intact classes were selected. One class functioned as the experimental group, which was instructed in the use of metacognitive strategies instruction (SQP2RS = Survey, Question, Predict, Read, Respond and Summarize) in reading classes. The other class was the control group, which was taught via a conventional reading instruction method (i.e. No metacognitive strategies intervention).

\subsection{Population and Sample}

The population of this quasi-experimental study consisted of all freshmen pre-intermediate (Level 2) students studying at the foundation program in the Waljat College of Applied Sciences in Oman in the second semester of the academic year 2017/2018. Seventy-six full-time students (13 male and 63 female) comprising four different sections (A, B, C and D) were involved. The classes were not segregated by gender as gender was not a variable of interest in the present study. The sample included two intact classes. One class was the experimental group, which received instruction relating to the metacognitive reading strategies (SQP2RS). The other class was the control group which received conventional reading instruction, i.e., basic reading instruction but no instruction of strategies (i.e. No metacognitive strategies intervention).

To verify the equivalence and homogeneity of the selected sections, students' reading midterm exam results plus their responses to a metacognitive awareness of reading strategies inventory were used. Based on the analysis of students' previous midterm results and their responses to the strategy use survey, sections A and B were selected as they were found to be the most homogeneous.

\subsection{Research Instruments}

\subsubsection{Reading Comprehension Test}

A reading comprehension test was designed to answer the first research question regarding the effect of metacognitive reading strategies instruction (SQP2RS = Survey, Question, Predict, Read, Respond and Summarize) on students' reading comprehension. Using authentic passages, the test was adapted from the TOEFL ${ }^{\circledR}$ Junior ${ }^{\mathrm{TM}}$ Standard test (2011) which is developed by the Educational Testing Service (ETS). According to the Hellenic American Union (2011), this test has three sections: Reading Comprehension, Listening Comprehension and Language Form and Meaning; however, the researchers only adapted the reading part of this test. This section consisted of 20 multiple-choice reading comprehension questions. The test consisted of three expository passages with a variety of lengths. As with most other global language proficiency tests, the test is not based on or limited to any specific curriculum (Hellenic American Union, 2011).

To ascertain the validity of the reading comprehension test, the initial version was submitted to a panel of 23 educators who commented on the clarity and relevance of each question of the test. To ascertain the reliability of the reading comprehension test, it was piloted on a group of 30 EFL foundation students at the pre-intermediate level, who were not included in the study sample. A split-half technique was used to obtain the correlation between the two halves of the test. Results revealed a 0.76 Pearson correlation, which indicated a high-reliability level.

Pre- and post-test scores were gathered for each student to measure changes in their reading comprehension performance before and after the metacognitive reading strategies instruction.

\subsubsection{Attitude Questionnaire}

To collect data related to the students' attitudes towards the use of the SQP2RS metacognitive reading strategies, a five-Likert scale attitude questionnaire (18 items) was developed and administered. The validity of the Attitude Questionnaire was maintained by a seven-member validation committee. Moreover, to ensure the reliability of the attitude questionnaire, it was piloted with 30 intermediate level 2 college foundation students who were not included in the main study. Reliability of the instrument (internal consistency) was determined utilizing Cronbach's Alpha obtained using SPSS. The reliability coefficient was found to be 0.828 , which indicated a high level of reliability.

\subsubsection{Metacognitive Reading Strategies (SQP2RS) Manual}

A Metacognitive Reading Strategies Teaching manual was prepared based on relevant studies in the field of metacognition and teaching language skills to foreign language learners (Pintrich, 2002; Baker, 2002; Echevarria, Vogt, \& Short, 2008; Al-Gharibi, 2016; Houtveen \& Van de Grift, 2007). The teaching manual included reading texts with reading comprehension activities and the procedures for teaching the reading texts based on metacognitive reading strategies. It also encompassed detailed worksheets based on SQP2RS, details on the 
reading comprehension cycle (before, during and after reading), examples of the SQP2RS note-taking process, lesson plans complete with specified time and procedures, a students' self-assessment tool and an array of follow up activities for expansion. The reading intervention was based on the existing commercial college coursebook (Weaving it Together 2) series from Heinle Cengage as well as some additional supplementary materials. To check its validity, the manual was given to 23 educators from various higher education institutes with experience of foundation level students in Oman to check the content and linguistic appropriateness of the manual.

\section{Results and Discussion}

\subsection{The Effect of Using SQP2RS on the Reading Comprehension of EFL Pre-Intermediate Foundation Students}

To answer the first research question, a post-trial reading comprehension test was administered to the experimental and the control group at the same time. An independent sample t-test was conducted to compare the experimental and control group students' posttest scores. Table 1 shows the results of the independent t-test sample of the mean scores in the posttest for the two groups.

Table 1. The Means and the standard deviations for the experimental and control groups' posttests scores $(n=45)$

\begin{tabular}{cccccccc}
\hline & Groups & $\mathrm{N}$ & Mean & SD & Df & t-value & Sig. (2-tailed) \\
\hline \multirow{2}{*}{ Posttest } & Experimental & 22 & 12.41 & 3.432 & 43 & 3.397 & $.001^{*}$ \\
& Control & 23 & 9.17 & 2.949 & 41.929 & & \\
\hline
\end{tabular}

*Significance level at $\alpha=0.05$.

Table 1 shows that there is a statistically significant difference between the mean scores of the posttest for both groups. The mean score for the experimental group and the control group were 12.41 and 9.17 respectively. The t-value was 3.397, which is significant at the 0.05 level in favor of the experimental group. Therefore, the results indicate that the experimental group outperformed the control group. This result is consistent with the results of several other studies (Auerbach \& Paxton, 1997; Kangli, 2002; Iwai, 2011; Wichadee, 2011; Takallou, 2011; Ismail, 2014; Pei, 2014) which have determined that teaching metacognitive reading strategies is useful in enhancing the students' reading comprehension performance.

To obtain a better understanding of the students' performance in the reading comprehension test in both the experimental and control groups, a paired sample t-test was conducted to evaluate the effect of the metacognitive reading strategies intervention. Table 2 displays the mean scores and standard deviations for both groups' pre and posttest scores.

Table 2. The means and the standard deviations for the experimental and control groups' pre and posttest scores $(n=45)$

\begin{tabular}{|c|c|c|c|c|c|c|c|c|}
\hline \multicolumn{3}{|c|}{ Group } & \multirow{2}{*}{$\frac{\text { Mean }}{9.05}$} & \multirow{2}{*}{$\frac{\mathrm{N}}{22}$} & \multirow{2}{*}{$\frac{\mathrm{SD}}{2.919}$} & \multirow{2}{*}{$\begin{array}{l}\mathrm{Df} \\
21\end{array}$} & \multirow{2}{*}{$\frac{\mathrm{t} \text {-value }}{4.819}$} & \multirow{2}{*}{$\frac{\text { Sig. (2-tailed) }}{.000^{*}}$} \\
\hline \multirow{2}{*}{ Experimental } & \multirow{2}{*}{ Pair 1} & Pretest & & & & & & \\
\hline & & Posttest & 12.41 & 22 & 3.432 & & & \\
\hline \multirow{2}{*}{ Control } & \multirow{2}{*}{ Pair 1} & Pretest & 9.09 & 23 & 3.592 & 22 & .234 & $.817 *$ \\
\hline & & Posttest & 9.17 & 23 & 2.949 & & & \\
\hline
\end{tabular}

*Significance level at $\alpha=0.05$.

Table 2 provides information about statistical differences in the mean scores of the pre and posttest scores for both groups. Regarding the experimental group, results show that there was a statistically significant increase in the mean scores. The mean score for the intervention group in the posttest was 12.41 compared to 9.17 for the control group indicating a large effect size. The t-value was 4.819 which is significant at the level of 0.05 in favor of the experimental group. This means that the experimental group has benefited positively from the metacognitive reading strategies intervention.

Concerning the control group, there was a slight increase in the mean scores of the posttest of the control group; from 9.09 to 9.17; which can be attributed to the reading lessons and the amount of time that the students spent in their reading classes for the duration of the present study (five weeks). However, there was no statistically significant difference in the mean scores of the pretest and posttest scores.

The study's results can be interpreted as signifying a beneficial role for the use of metacognitive reading strategies 
in helping readers achieve better comprehension when reading a text in an EFL setting, which resonates with several other studies (e.g. Auerbach \& Paxton, 1997; Kangli, 2002; Iwai, 2011; Wichadee, 2011; Takallou, 2011; Pei, 2014; Ismail, 2014; Kamalia, 2016). The use of reading strategies can help readers overcome comprehension issues which arise while reading in ESL/EFL contexts, and, accordingly, students' reading comprehension can be improved. Remarkably, in all of the aforementioned studies, the experimental group significantly outperformed the control group on reading performance assessments.

\subsection{Students'Attitudes towards the SQP2RS Strategy in Reading Classes}

To investigate the experimental students' attitudes towards the use of SQP2RS metacognitive reading strategies, a five-point Likert scale questionnaire was administered to them after the intervention ended. The questionnaire aimed at identifying areas that students believed the strategies instruction has helped them with. Descriptive statistics (i.e. means and standard deviations) were obtained to analyze students' responses.

The grand mean of all attitudinal items was 4.04, which indicates that students in the experimental group had a positive attitude towards strategy use. This, therefore, suggests that foundation students had positive experiences implementing the metacognitive reading strategies when approaching reading comprehension texts. These findings are consistent with many research studies conducted in the area of reading strategies and cognition (Carrel, 1989; Al Shaihani, 2002; Al-Farsi, 2009). It appears that students who were taught metacognitive reading strategies in their reading classes have become aware of different reading strategies and their proper implementation, and they have begun to be conscious of what is happening in their minds while reading. This conscious awareness of the cognitive processes that students gain while reading is believed to improve not only their comprehension performance but also their thinking skills.

The questionnaire items were classified into two main categories: cognitive and affective. The cognitive part deals with the cognitive factors affecting students' attitudes towards metacognitive reading strategies; the affective part deals mostly with motivational factors.

\subsubsection{The Cognitive Aspect of the Questionnaire}

Metacognitive reading strategies allow learners to exploit their knowledge of cognitive processes such as planning, monitoring, and evaluating to regulate their learning (Carrell, 1989). The attitudes questionnaire targeted the extent to which students in the experimental group recognized that the strategies have helped them benefit cognitively. Table 3 below displays the means and standard deviations of the items addressing the cognitive theme.

Table 3. Means and standard deviations of items addressing cognitive themes $(n=45)$

\begin{tabular}{|c|c|c|}
\hline Metacognitive reading strategies that my teacher used in the reading classes: & Mean* & $S D$ \\
\hline 3. Helped me look for text features like title, bolded words, pictures, headings and subheadings, which aid my understanding. & 4.35 & .982 \\
\hline 8. Assisted me to make connections between information in the reading texts and my prior knowledge (what I already know). & 4.22 & .850 \\
\hline $\begin{array}{l}\text { 7. Made me aware of using appropriate reading strategies for each stage of reading (before reading, while reading and after } \\
\text { reading). }\end{array}$ & 4.22 & .736 \\
\hline 10. Helped me plan steps for answering comprehension questions. & 4.09 & .949 \\
\hline 17. Made me integrate ideas from different parts of the text. & 4.04 & .976 \\
\hline 5. Helped me gain a deeper understanding by generating questions while reading a text. & 4.04 & .825 \\
\hline 15. Helped me set a purpose before reading a text. & 4.04 & .706 \\
\hline 13. Made me able to differentiate key information to the text. & 4.00 & .798 \\
\hline 12. Encouraged me to anticipate what is coming next in the text. & 3.96 & .976 \\
\hline 11. Helped me make guesses about unknown words using context clues. & 3.87 & .815 \\
\hline 16. Assisted me to summarize key information and facts important to the text. & 3.83 & .778 \\
\hline 4. Made me make predictions about the text content through a picture or the title. & 3.83 & .717 \\
\hline 14. Helped me engage in higher thinking processes such as critical analysis and evaluation. & 3.70 & .974 \\
\hline Total & 4.01 & .852 \\
\hline
\end{tabular}

* The highest score $=5$ (on a five-point Likert scale).

Table 3 above presents the means and standard deviations of the students' responses to items addressing cognitive strategies. The grand mean for all attitudinal items related to cognition was 4.01 with a standard deviation of .852 , which indicates that most of the students in the experimental group have gained cognitive benefits from the 
SQP2RS strategy while answering reading texts. The highest mean score was 4.35 , for the statement, 'SQP2RS helped me look for text features like title, bolded words, pictures, headings and subheadings which aid my understanding'. This reveals that metacognitive reading strategies helped students' comprehension by prompting them to look at the many useful text features and structure, which according to Bolter (2001), provides many cues. This points to the importance of metacognitive reading strategies in the pre-reading phase (global reading strategies). The statement 'SQP2RS helped me set a purpose before reading a text' (mean 4.04) is also addressing pre-reading or planning strategies. Furthermore, anticipating text features including headings, subheadings and purpose, enables readers to develop a deeper view of the text as they assimilate its content into their pre-existing schema and therefore decide how to approach it. Ultimately, readers who can understand text structures, meaning passage titles, section headings and subheadings, key vocabulary, figures and diagrams, are much more successful in accessing the information in a text (Israel, 2007; Pressley, 2002).

Additionally, the statements'SQP2RS assisted me to make connections between information in reading texts and my prior knowledge (what I already know)', and 'SQP2RS made me aware of using appropriate reading strategies for each stage of reading (before reading, while reading and after reading' both recorded mean scores of (4.22), which suggests the effective impact of metacognitive reading strategies during the three reading phases: pre-reading, during reading and post-reading. This shows that metacognitive reading strategies assist pre-intermediate foundation students not only in improving their understanding of how to connect the information to their schemata but also in raising awareness of the appropriate strategies that can be applied in each reading phase. Furthermore, the statements 'SQP2RS helped me plan steps for answering comprehension questions', 'SQP2RS made me integrate ideas from different parts of the text', 'SQP2RS helped me gain a deeper understanding by generating questions while reading a text', 'SQP2RS helped me make guesses about unknown words using context clues' and 'SQP2RS assisted me to summarize key information and facts important to the text' obtained mean scores of (4.09), (4.04), (4.04), (3.87) and (3.83) respectively. This reveals that the students in the experimental group gained problem-solving (or monitoring) metacognitive strategies that readers use to control comprehension at the actual reading phase. Problem-solving strategies are those deployed by the reader to aid understanding and include summarizing ideas, paraphrasing sentences, writing comments, inferring meanings of unfamiliar words, and integrating ideas from different parts of the text. These strategies can play a crucial role in how a reader develops an understanding of a text. Developing such strategies encourages students to thoroughly structure their reading process and promote active reading skills that can consequently help students make sense of a text (Israel, 2007; Pressley, 2002; Al-Khamisi, 2016). The study's findings lend support to those reported by Garner (1990) and Nist and Holshuh (2000) who found out that better readers use various metacognitive reading strategies to aid their comprehension. Their results revealed that better readers wrote comments and summaries of the texts while scrutinizing the text for details. They also concluded that competent readers inferred meanings of unfamiliar words using clues provided in the context. Additionally, their results highlighted the fact that compared to other readers, better readers promote their comprehension by finding connections between different parts of the text as well as asking questions while going through the text.

The pre-intermediate foundation students in this study also reported that SQP2RS made them actively engaged in higher thinking processes as they incorporate the text into their schema. This is reflected in the statement 'SQP2RS helped me engage in higher thinking processes to understand the text'. The lowest mean value (3.70) was for the statement: 'SQP2RS helped I engage in higher thinking processes such as critical analysis and evaluation'. This statement is related to evaluating metacognitive strategies, which is the highest level of difficulty. Although 3.70 is considered a high mean score, as it was the lowest mean score compared to the other items in the questionnaire, it can be considered revealing. It could be attributed to the level of English proficiency of the pre-intermediate students in the foundation program. Weakness in reading, as revealed by Cobb's study, (1999), can be due to comprehension deficiency caused by a failure in both understanding words and also constructing meanings through higher level thinking skills including analysis, synthesis and evaluation (cited in Al-Mahrooqi, 2012). The fact that these students may lack sufficient critical thinking and evaluation skills as a result of their experiences in schools is a concern that has been reported by many researchers in the Omani context (Al-Mahrooqi \& Asante, 2010; Al Seyabi \& Tuzlukova, 2015; Cahyono \& Widiati, 2006; Moody, 2009; Moss \& Bordelon, 2007; Sivaraman et al, 2014; Al-Gharibi, 2016). As reported by Al Seyabi and Tuzlukova (2014) these higher-level skills have a certain degree of difficulty for which pre-intermediate foundation students simply cannot handle.

\subsubsection{Questionnaire Items Relating to Affect}

The metacognitive reading strategies intervention questionnaire takes into consideration the affective aspect of the participants in the experimental group. Table 4 below displays the means and the standard deviations of the items related to the affective aspects of the attitude questionnaire. 
Table 4. Means and standard deviations of items relating to affect $(n=45)$

\begin{tabular}{lcc}
\hline Statements & Mean* & SD \\
\hline 18. Made me decide to use reading strategies when answering reading comprehension questions in the future. & 4.35 & .832 \\
1. Made me more self-confident while reading texts. & 4.30 & .635 \\
9. Helped me have a positive attitude toward reading. & 4.09 & .900 \\
6. Made me more willing to answer comprehension questions. & 4.09 & .793 \\
2. Made me enjoy the reading classes more. & 3.87 & .968 \\
Total & 4.14 & .825 \\
\hline
\end{tabular}

* The highest score $=5$ (on a five-point-Likert-scale).

Table 4 shows the mean scores and standard deviations of pre-intermediate students' responses to the items concerning affect. The grand mean score for all items related to affect was (4.14) which indicates a high level of agreement across the experimental group students. Results revealed that the SQP2RS intervention had an influential and long-lasting effect on the students as it made them decide to use reading strategies when answering reading comprehension questions in the future $(\mathrm{M}=4.35)$. Regarding the motivational effect of developing self-confidence in learners $(\mathrm{M}=4.30)$, the data showed that the effects of the SQP2RS program were of great benefit to EFL students in boosting their confidence in dealing with comprehension questions. Many researchers (Chamot \& Kupper, 1989; Wenden, 1991; Iwai, 2011; Aghaie \& Zhang, 2012; Khajavi, \& Abbasian, 2014; Kamalia, 2016, Al-Gharibi, 2016) have asserted that equipping students with metacognitive reading strategies can lead to readers becoming more autonomous, strategic and independent. Likewise, Shinn (1998), and Gordon and $\mathrm{Lu}$ (2008) reported that students became more independent and self-confident after learning strategies. The statements 'SQP2RS helped me have a positive attitude toward reading' and 'SQP2RS made me more willing to answer comprehension questions' both obtain a mean value of 4.09. Both mean scores indicate that the SQP2RS strategy contributed to improving students' confidence and their willingness to engage with reading comprehension tasks. Interestingly, students reported that the strategy made them enjoy the reading classes more (mean $=3.87)$. It can be therefore deduced that the intervention had a stimulating influence on the overall satisfaction levels of the reading course participants, which in turn made students enjoy reading sessions and develop more positive attitudes towards EFL reading in general.

\section{Conclusion}

The current study investigated the extent to which a metacognitive reading strategies intervention influenced EFL pre-intermediate foundation students in Oman. The study employed a reading comprehension test to measure the difference in the students' reading performance before and after a 25 -hour intervention. In addition to the students' performance, the present study also examined students' attitudes towards strategies use using a questionnaire.

Based on the findings, this study revealed that Omani EFL pre-intermediate foundation students have benefited positively from the metacognitive reading strategies treatment. Analysis from the test showed that there were statistically significant differences between the group that received the metacognitive treatment and the group which received conventional reading instruction. Besides, the study uncovered that there were no statistically significant differences in mean reading comprehension test scores between the pretest and posttest for the control group indicating that teaching reading without covering metacognitive strategies may result in less than positive learning outcomes and could cause students' levels to plateau.

The effect of the treatment was not limited to improving students' reading performance, but it also fostered positive student attitudes and increased motivation towards reading in general. This study, along with others, has shown that metacognitive strategies instruction leads to improvements in many affective aspects related to learning. Responses to the questionnaire also indicated that the pre-intermediate foundation level learners developed more self-confidence, self-efficacy and autonomy - all of which, in turn, serve the ultimate learning aim of building a learner-centered learning culture at the tertiary level.

The findings of the current study are aligned towards achieving academic intended outcomes as prescribed by the academic accreditation institutes including the AAA; which centers on the notion that the student should be the driver of the learning process. The achievement of standards set by institutions such as the AAA should be met through students' successfully meeting intended learning outcomes (Al-Mashani, 2011). Therefore, in the context of second and foreign language learning, learners have to gain not only knowledge about strategies but also improve their conscious awareness and positive attitudes which together combine to ensure successful learning 
outcomes.

\section{Implications}

\subsection{Implications for Curriculum Designers}

Understanding the significant role of metacognition in reading and the most appropriate methods of providing instruction needs a closer look from administrators, curriculum designers and subject coordinators to adopt metacognitive strategies in teaching reading so that intended learning outcomes are met successfully. This recommendation is not limited to foundation program educators but also policymakers in the Ministry of Education. Teaching metacognitive strategies helps enable students to become more autonomous readers as well as develop critical thinking skills. This study, along with others, have highlighted the fact that these higher-order skills are sorely lacking in Omani school graduates who are generally unprepared for tertiary study (Al Seyabi \& Tuzlukova, 2015; Cahyono \& Widiati 2006; Moss \& Bordelon, 2007; Al-Mahrooqi, 2012; Sivaraman et al., 2014).

Adopting the instruction of these strategies into the current foundation program curriculum would be a relatively straightforward task for curriculum designers or subject coordinators in that the course syllabus does not need to be rewritten to meet the required outcomes. Stakeholders in private and public colleges and the Ministry of Education should consider offering training programs for trainee teachers and subject coordinators involving metacognitive reading strategies to equip current and incoming teachers with the required knowledge.

Moreover, designers of both teacher's guides and student course books should allocate adequate time for strategies instruction on a gradual base for reading classes. As metacognitive strategies involve activating higher order thinking skills, care should be taken in the first few reading sessions so that enough time is spent helping students to absorb and affectively understand and appreciate these strategies.

\subsection{Implications for Teachers}

Teachers in the field of teaching English have to strive to make the learning process more effective. It is the teachers' responsibility to instruct the students on the rationale behind using these strategies, when and how to use them and the appropriate strategy to use for each reading phase. Working on the students' application of strategies leads to improvements in attitude, motivation and so is essential for the achievement of reading goals. Teachers should spend sufficient time not only in training their students on metacognitive strategies but also in raising their awareness of the gains they might reap when applying these strategies.

To ensure maximum benefit from teaching metacognitive strategies in real classroom interactions, it is of considerable importance that the intervention starts with a modelling phase in which the teacher verbally reveals to the class the cognitive processes they undertake while applying metacognitive strategies on reading texts. This modelling phase may need to be extended to two or three times, depending on the students' level of understanding and feedback. Teachers are also encouraged to involve students in the modelling process as learners can verbalize their cognitive processes while approaching a text. This can involve group or individual attempts to elaborate on the strategy implementation as a student's point of view can pave the way for other learners to comprehend more easily. By using and applying metacognitive reading strategies to foundation level and high school learners we are facilitating the development of more active, autonomous, strategic, and analytic readers.

\section{References}

Afflerbach, P., Pearson, P., \& Paris, S. (2008). Clarifying differences between reading skills and reading strategies. The Reading Teacher, 61, 364-373. https://doi.org/10.1598/RT.61.5.1

Aghaie, R., \& Zhang, L. (2012). Effects of explicit instruction in cognitive and metacognitive reading strategies on Iranian EFL students' reading performance and strategy transfer. Instructional Science, 40(6), 1063-1081. https://doi.org/10.1007/s11251-011-9202-5

Al Rabah, S. \& Wu, S. (2019). A descriptive analysis of the metacognitive reading strategies employed by EFL college students in Kuwait. International Journal of English Linguistics, 9(1), 25-35. https://doi.org/10.5539/ijel.v9n1p25

Al Seyabi, F., \& Tuzlukova, V. (2015). Investigating EFL reading problems and strategies in post-basic schools and university foundation programs: A study in the Omani context. Malaysian Journal of ELT Research, 11(2), 35.

Al-Farsi, H. (2009). Effect of a metacognitive reading strategy on Omani students' reading performance and attitudes (Unpublished M.A. Thesis). Sultan Qaboos University, Oman.

Al-Gharibi, S. (2016). The Effect of a question-answer relationships (QARs) strategy on the reading 
comprehension of Omani female EFL grade ten students (Unpublished M.A. thesis). Sultan Qaboos University, Oman.

Al-Khamisi, H. (2016). Gender gap in reading: The impact of reading self-efficacy beliefs on EFL reading achievement (Unpublished M.A. thesis). Sultan Qaboos University, Oman.

Al-Mahrooqi, R. \& Asante, C. (2010). Promoting autonomy by fostering a reading culture. In R. Al-Mahrooqi, \& V. Tuzlukova (Eds.), The Omani ELT Symphony: Maintaining Linguistic and Socio-Cultural Equilibrium (pp. 477-494). Muscat: Sultan Qaboos University Academic Publication Board.

Al-Mahrooqi, R. (2012). English communication skills: How are they taught at schools and universities in Oman? English Language Teaching, 5(4), 124-130. https://doi.org/10.5539/elt.v5n4p124

Al-Mamari, A. (2010). Analysing results of placement tests in private higher education institutions. Unpublished report, Ministry of Higher Education, Sultanate of Oman.

Al-Mashani, F. (2011). Aligning general education diploma's outcomes with higher education requirement in the Sultanate of Oman. A thesis submitted as a requirement for an MA in Education. Sultan Qaboos University, Sultanate of Oman.

Al-Mekhlafi, A. (2018). EFL learners' metacognitive awareness of reading strategies. International Journal of Instruction, 11(2), 297-308. https://doi.org/10.12973/iji.2018.11220a

Anderson, R., Hiebert, E., Scott, J., \& Wilkinson, I. (1985). Becoming a nation of readers. Champaign, IL: University of Illinois. Center for the Study of Reading.

Auerbach, E., \& Paxton, D. (1997). "It's not the English thing": Bringing reading research into the ESL classroom. TESOL Quarterly, 31, 237-261. https://doi.org/10.2307/3588046

Baker, L. \& Brown, A. (1984). Metacognitive skills of reading. In D. Pearson (Ed.), Handbook of Reading Research. New York: Longman.

Baker, L. (2002). Metacognition in comprehension instruction. In C. C. Block, \& M. Pressley (Eds.), Comprehension instruction: Research- based best practices (pp. 77-95). New York: Guilford Press.

Bolter, J. (2001). Writing space: Computers, hypertext, and the remediation of print. Mahwah, NJ: Lawrence Erlbaum Associates, Publishers. https://doi.org/10.4324/9781410600110

Cahyono, B., \& Widiati, U. (2006). The teaching of EFL reading in the Indonesian context: The state of the art. TEFLIN Journal, 17(1), 36-58.

Carrell, P. (1989). Metacognition awareness and second language reading. Modern Language Journal, 73(2), 121-134. https://doi.org/10.1111/j.1540-4781.1989.tb02534.x

Carrell, P., Pharis, B., \& Liberto, J. (1989). Metacognitive strategy training for ESL reading. TESOL Quarterly, 647-678. https://doi.org/10.2307/3587536

Carroll, M., Razvi, S., \& Goodliffe, T. (2009). Using Foundation Program Academic Standards as a Quality Enhancement Tool. A paper for INQAAHE 2009. Retrieved from http://www.oac.gov.om/qe/oqn

Caverly, D., Nicholson, S., \& Radcliffe, R. (2004). The effectiveness of strategic reading instruction for college developmental readers. Journal of College Reading and Learning, 35(1), 25-49. https://doi.org/10.1080/10790195.2004.10850166

Chamot, A., \& Kupper, L. (1989). Learning strategies in foreign language instruction. Foreign language annals, 22(1), 13-22. https://doi.org/10.1111/j.1944-9720.1989.tb03138.x

Chamot, A. (2005). Language learning strategy instruction: Current issues and research. Annual Review of Applied Linguistics, 25, 112-130. https://doi.org/10.1017/S0267190505000061

Cobb, T. (1999). Applying constructivism: A test for the learner-as-scientist. Educational Technology Research \& Development, 47(3), 15-33. https://doi.org/10.1007/BF02299631

Echevarria, J., Vogt, M., \& Short, D. (2008). Making content comprehensible for English learners: The SIOP model. Pearson. https://doi.org/10.18848/1447-9494/CGP/v14i11/45514

Garner, R. (1990). When children and adults do not use learning strategies: Toward a theory of settings. Review of educational research, 60(4), 517-529. https://doi.org/10.3102/00346543060004517

Grabe, W., \& Stoller, F. (2002). Teaching and researching reading. Harlow: Pearson Education Limited.

Guterman, E. (2003). Integrating written metacognitive awareness guidance as a 'psychological tool' to improve 
$\begin{array}{llll}\text { student } & \text { Lerformance. }\end{array}$ https://doi.org/10.1016/S0959-4752(02)00070-1

Harris, A., McGregor, J., Perencevich, E., Furuno, J., Zhu, J., Peterson, D., \& Finkelstein, J. (2006). The use and interpretation of quasi-experimental studies in medical informatics. https://doi.org/10.1197/jamia.M1749

Hellenic American Union (2011). Reading comprehension sample questions. Retrieved from https://www.ets.org/toefl_junior/prepare/standard_sample_questions/reading_comprehension

Hismanoglu, M. (2000). Language learning strategies in foreign language learning and teaching. The Internet TESL Journal, 6(8), 12-12.

Houtveen, A., \& Van de Grift, W. (2007). Effects of metacognitive strategy instruction and instruction time on reading comprehension. School Effectiveness and School Improvement, 18(2), 173-190. https://doi.org/10.1080/09243450601058717

Ismail, N. (2014). Effectiveness of a metacognitive reading strategies program for improving low achieving EFL readers. International Education Studies, 8(1), 71. https://doi.org/10.5539/ies.v8n1p71

Israel, S. (2007). Using metacognitive assessments to create individualized reading instruction. International Reading Association. Newark.

Kamalia, K. (2016). Improving reading comprehension using the survey, question, predict, read, respond, and summarize (SQP2RS) strategy. English Education Journal, 7(4), 549-564.

Kangli, J. (2002). Metacognitive strategy training in EFL learning. Foreign Language World, 2, 20-26.

Khajavi, Y., \& Abbasian, R. (2014). Improving EFL students' self-regulation in reading English using a cognitive tool. The Journal of Language and Linguistic Studies, 9(1), 206-222.

Lam, W. (2008). Metacognitive strategy use: Accessing ESL learners' inner voices via stimulated recall. Innovation in Language Teaching and Learning, 2(3). https://doi.org/10.1080/17501220802158917

Lau, K., \& Chan, D. (2003). Reading strategy use and motivation among Chinese good and poor readers in Hong Kong. Journal of Research in Reading, 26(2), 177-190. https://doi.org/10.1111/1467-9817.00195

Marimuthu, R., Muthusamy, C., \& Veeravagu, J. (2016). Metacognitive strategy training through the cognitive academic language learning approach (CALLA) as a way to improve reading comprehension performance among students of an English language course at UiTM Penang. Malaysian Journal of ELT Research, 7(1), 64-93.

Mokhtari, K., \& Reichard, C. (2002). Assessing students' metacognitive awareness of reading strategies. Journal of Educational Psychology, 94(2), 249-259. https://doi.org/10.1037/0022-0663.94.2.249

Mokhtari, K., \& Sheorey, R. (2002). Measuring ESL students' reading strategies. Journal of Developmental Education, 25(3), 2-10.

Moody, J. (2009). A neglected aspect of ELT in the Arabian Gulf: Who is communication between? In L. Zhang, R. Rubdy, \& L. Alsagoff (Eds.), Englishes and literatures-in-English in a globalized world: Proceedings of the 13th International Conference on English in Southeast Asia (pp. 99-119). Singapore: National Institute of Education, Nanyang Technological University.

Moss, B., \& Bordelon, S. (2007). Preparing students for college level reading and writing: Implementing a rhetoric and writing class in the senior year. Reading Research and Instruction, 46(3), 197-221. https://doi.org/10.1080/19388070709558468

Nist, S. \& Holschuh, J. (2000). Comprehension strategies at the college level. In R. Flippo, \& D. Caverly, (Eds.), Handbook of college reading and study strategies (pp. 75-104). Mahwah, NJ: Lawrence Erlbaum Associates.

O’Malley, M., \& Chamot, A. (1990). Learning strategies in second language acquisition. New York: Cambridge University Press. https://doi.org/10.1017/CBO9781139524490

Oman Academic Accreditation Authority. (2008). Oman Academic Standards for General Foundation Programs.

Oxford, R. (1990). Language learning strategies: What every teacher should know. Boston, MA: Heinle \& Heinle Publishers.

Ozek, Y., \& Civelek, M. (2006). A study on the use of cognitive reading strategies by ELT students. The Asian EFL Journal, 14(1), 1-26. 
Pei, L. (2014). Does metacognitive strategy instruction indeed improve Chinese EFL Learners' reading comprehension performance and metacognitive awareness. Journal of Language Teaching and Research, 5(5), 1147-1152. https://doi.org/10.4304/jltr.5.5.1147-1152

Pintrich, P. (2002). The role of metacognitive knowledge in learning, teaching, and assessing. Theory into practice, 41(4), 219-225. https://doi.org/10.1207/s15430421tip4104_3

Pressley, M. (2002). Metacognition and self-regulated comprehension. In A. Farstrup, \& S. Samules (Eds.), What research has to say about reading instruction (3rd ed., pp. 291-309). Newark, DE: International Reading Association. https://doi.org/10.1598/0872071774.13

Pressley, M., \& Afflerbach, P. (1995). Verbal protocols of reading: The nature of constructively responsive reading. Routledge. https://doi.org/10.2307/358808

Ratna, A. (2014). The Use of Cognitive Reading Strategies to Enhance EFL Students' Reading Comprehension. International Journal of Education, 2(1), 1-11.

Reutzel, D., Smith, J., \& Fawson, P. (2005). An evaluation of two approaches for teaching reading comprehension strategies in the primary years using science information texts. Early Childhood Research Quarterly, 20(3), 276-305. https://doi.org/10.1016/j.ecresq.2005.07.002

Singhal, M. (2001). Reading proficiency, reading strategies, metacognitive awareness and L2 readers. The Reading Matrix, 1(1).

Sivaraman, I., Al Balushi, A., \& Rao, D. (2014). Understanding Omani students'(University) English language problems. International Journal of Sciences: Basic and Applied Research (IJSBAR), 13(1), 28-35.

Snow, C. (2002). Reading for understanding: Toward an R\&D program in reading comprehension. Rand Corporation.

Takallou, F. (2011). The effect of metacognitive strategy instruction on EFL learners' reading comprehension performance and metacognitive awareness. Asian EFL Journal, 13(1).272-300.

Tavakoli, H. (2014). The effectiveness of metacognitive strategy awareness in reading comprehension: The case of Iranian university EFL students. Reading, 14(2), 314-336.

Wenden, A. (1991). Learner strategies for learner autonomy. New York.

Wenden, A. (1998). Metacognitive knowledge and language learning. Applied Linguistics, 19(4), 515-537. https://doi.org/10.1093/applin/19.4.515

Wenden, A., \& Rubin, J. (Eds.). (1987). Learning strategies in language learning. Prentice-Hall International.

Wichadee, S. (2011). The effects of metacognitive strategy instruction on EFL Thai students' reading comprehension ability. Journal of College Teaching and Learning, 8(5), 31. https://doi.org/10.19030/tlc.v8i5.4255

Yore, L., Craig, M., \& Maguire, T. (1998). Index of science reading awareness: An interactive-constructive model, test verification, and grades 4-8 results. Journal of Research in Science Teaching, 35(1), 27-51. https://doi.org/10.1002/(SICI)1098-2736(199801)35:1<27::AID-TEA3>3.0.CO;2-P

Zhang, L., \& Seepho, S. (2012). Effects of MST (Metacognitive Strategy Training) on Academic Reading Comprehension of Chinese EFL Students. US-China Foreign Language, 10(2), 933-943.

\section{Copyrights}

Copyright for this article is retained by the author(s), with first publication rights granted to the journal.

This is an open-access article distributed under the terms and conditions of the Creative Commons Attribution license (http://creativecommons.org/licenses/by/4.0/). 